our pursuit of the aims defined by His Royal Highness, and on all these counts we now desire to express to Your Majesty our humble gratitude. J. H. Jeans, President." The following reply was received from Sir Clive Wigram : "I am commanded by the King to thank the members of the British Association for the Advancement of Science for the loyal message which they have addressed to His Majesty, their Patron, from the Inaugural General Meeting in the Ancient City of Aberdeen. His Majesty appreciates their kind remembrance of the occasion when the Prince Consort, as President of the Association, delivered a message from Queen Victoria to the members assembled in this City three quarters of a century ago. The King desires me to assure the members of his unabated interest in their Meetings and his confidence that their investigations into the manifold problems confronting present day Scientists will continue to be productive of results which will benefit mankind. Clive Wigram."

THe report of the Council of the British Association, adopted by the General Committee at Aberdeen on September 5, records that the Local Committee for the Leicester meeting has presented the sum of $£ 1,000$ to the Association, being the unexpended balance of the fund raised locally for the purposes of the meeting. This gift has been gratefully accepted, and the sum will be invested to form a Leicester and Leicestershire Fund, the interest of which will be used "to assist by scholarship or otherwise a student or students working for the advancement of science". Five new members of Council were elected by the General Committee, namely, Sir T. Hudson Beare, Prof. A. V. Hill, Dr. W. W. Vaughan, Dr. W. T. Calman and Prof. H. M. Hallsworth. Future meetings of the Association will be at Norwich, 1935 (September 4-11); Blackpool, 1936 ; Nottingham, 1937; Cambridge, 1938; Dundee, 1939 or 1940. Sir Josiah Stamp announced at the conclusion of the inaugural meeting at Aberdeen that the membership for the meeting had reached a total of 2,784 .

\section{Causation of Cancer}

IN a paper published in Medizinische Welt of August 25, Dr. W. von Brehmer claims to have obtained in pure culture an organism, present in the blood of cancorous patients and of animals bearing tumours. The organism could also be obtained from human and animal tumours. It is a pleomorphic aerobe which in pure culture appears in the form of tubules $0.5 \mu-2.8 \mu$ long and $0.2 \mu-0.8 \mu$ broad, and can be stained by a Giemsa stain. The tubules are filled with spores, which when liberated, are stated to be able to enter damaged cells and thus cause cancer. An essential condition for obtaining cultures of this organism, to which the name Syphonospora polymorpha has been given, is an alkaline condition of the medium, with a $p H$ of $7 \cdot 5-7 \cdot 6$, and von Brehmer maintrins that cancer is always associated with a shift of the hydrogen ion concentration of the blood toward the alkaline side. The organism is stated to exist in the blood of apparently normal healthy people in the form of small spores which are non-pathogenic, but become pathogenic with the shift of the hydrogen ion concentration. Dr. von Brehmer also claims to have produced tumours in animals by the injection of pure cultures of his organism, but no detailed evidence is given.

Dr. von BreHMer's paper is followed by a paper by $V$. Schilling, who has repeated these experiments, partly with von Brehmer's assistance. He has succeeded in obtaining pure cultures of this organism from malignant tissues and from the blood of cancer patients and of animals bearing tumours. His experiments on the production of cancer in animals by inoculation of these tumours have, however, given negative results. $\mathrm{He}$ is, therefore, inclined to regard the presence of this organism as being due to a mixed infection or to its being a non-pathogenic symbiont, and he dissociates himself from the therapeutic and diagnostic conclusions drawn by von Brehmer from his work. The existence of a relatively large, visible and stainable organism as the cause of cancer is difficult to reconcile with many of the well. established facts concerning cancer. Moreover, the existenee of an alkalosis in cancer, which von Brehmer considers to be an essential feature of cancer, is questionable and several competent obsërvers using exact methods have failed to demonstrate it. It has been reported (Times, September 10) that von Brehmer's claims will be submitted to an official investigation, initiated by the authorities in Germany. Until the results are known, it is necessary to reserve judgement.

\section{Food Storage and Transport}

ON September 7, Sir Frank Smith, Secretary of the Department of Scientific and Industrial Research, delivered the Hardy Memorial Lecture before the British Association at Aberdeen, in which he paid tribute to the work of the late Sir William Hardy, who during the last seventeen years of his life, devoted much of his time to research on the transport and storage of foodstuffs. Sir Frank described the work being done on the kippered herring at the Torry Research Station, Aberdeen, which was founded by Sir William Hardy. A now kippering kiln has been evolved there, in which all variables such as temperature, humidity, etc., can be controlled. Thus, any desired cure can be produced with certainty. At the same station, a new kind of mild salted herring has been produced by the combined processes of salting and chilling. About 1,600 steam trawlers fish from the ports of Great Britain, landing nearly 700,000 tons of white fish valued at about $12 \frac{1}{2}$ million sterling each year. Storage in crushed ice, under conditions prevailing when Hardy took up the problem in 1929, could only hold such fish fresh for 6-7 days. To-day, work at the Torry Station has extended that period to 12 days, by reducing bacterial contamination. Further work has shown that freezing in brine at $-20^{\circ} \mathrm{C}$. and storing at the same temperature will keep the fish for three months. The 10,000-ton vessel Arctic Queen, fitted as a floating factory for halibut, was also described. The importance of refrigeration cannot be over- 